\title{
Effect of Casuarina Crushed Nodules, Rhizospheric Soil and Leaves Compost on Salt Tolerance of Casuarina equisetifolia L. and Casuarina obesa Miq.
}

\author{
Marie Claver Ndébane Ngom ${ }^{1,2}$, Pape Ibrahima Djighaly 1,2,3,4, Nathalie Diagne ${ }^{1,3 *}$, \\ Maty Ndour 1,2, Ganna Ndong1, Daouda Ngom ${ }^{5}$, Mariama Ngom ${ }^{3,4,5}$, \\ Saliou Ngom6, Sergio Svistoon off 4 ,7 \\ ${ }^{1}$ Centre National de Recherches Agronomiques (ISRA/CNRA), Bambey, Sénégal \\ ${ }^{2}$ Département d'Agroforesterie, Université Assane Seck de Ziguinchor, Ziguinchor, Sénégal \\ ${ }^{3}$ Laboratoire Commun de Microbiologie LCM: (IRD/ISRA/UCAD), Centre de Recherche de Bel Air, Dakar, Sénégal \\ ${ }^{4}$ Laboratoire Mixte International Adaptation des Plantes et Microorganismes Associés aux Stress Environnementaux (LAPSE), \\ Centre de Recherche de Bel Air, Dakar, Sénégal \\ ${ }^{5}$ Département de Biologie Végétale, Université Cheikh Anta Diop de Dakar, Dakar, Sénégal \\ ${ }^{6}$ Centre pour le Développement de l'Horticulture (ISRA/CDH), Cambérène, Dakar, Sénégal \\ ${ }^{7}$ Laboratoire des Symbioses Tropicales et Méditerranéennes (LSTM), Université de Montpellier, CIRAD, INRAE, IRD, Institut \\ Agro, Campus International De Baillarguet, Montpellier, France \\ Email: *nathaliediagne@gmail.com
}

How to cite this paper: Ngom, M.C.N., Djighaly, P.I., Diagne, N., Ndour, M., Ndong, G., Ngom, D., Ngom, M., Ngom, S. and Svistoonoff, S. (2020) Effect of Casuarina Crushed Nodules, Rhizospheric Soil and Leaves Compost on Salt Tolerance of Casuarina equisetifolia L. and Casuarina obesa Miq.. Open Journal of Soil Science, 10, 359-373.

https://doi.org/10.4236/ojss.2020.109019

Received: June 26, 2020

Accepted: September 12, 2020

Published: September 15, 2020

Copyright $\odot 2020$ by author(s) and Scientific Research Publishing Inc. This work is licensed under the Creative Commons Attribution International License (CC BY 4.0).

http://creativecommons.org/licenses/by/4.0/

\section{Open Access}

\begin{abstract}
Soil salinization is one of the major causes of land degradation. In Senegal, this phenomenon continues to grow, making soils unsuitable for agriculture. To rehabilitate salty lands, one of the recommended strategies is the use of salt-tolerant plants. Among them, plants of Casuarinaceae family form a relationship with symbiotic microorganisms such as arbuscular mycorrhizal fungi and nitrogen fixing bacteria. It has been shown that symbiotic microorganisms play an important role in the establishment of tolerant plants in saline conditions (Djighaly et al., 2018). They improve plant performance and reduce transplant shock under salt stress conditions (Diagne et al., 2014). These microorganisms can be used as biofertilizers. However, inocula containing symbiotic microorganisms are either too expensive or unavailable in many developing countries. The aim of this study is to test alternatively affordable and low-tech solutions to promote symbiotic interactions such as Casuarina crushed nodule, Casuarina rhizosphere soil and Casuarina leaves compost that may contain symbiotic microorganisms and also nutrients such as $\mathrm{N}$ and phosphorus. Two species of Casuarina (Casuarina equisetifolia L. and Casuarina obesa Miq.) were grown in the greenhouse on sterile soil to which an
\end{abstract}


amendment was added (Casuarina crushed nodules, Casuarina Rhizospheric soil or Casuarina leaves compost). Plants were subjected to saline stress. After four months of cultivation, they were harvested and morphological and physiological parameters were determined. Results showed that inoculation with Casuarina crushed nodules, Casuarina rhizospheric soil and Casuarina leaves compost improved growth, total dry biomass, total chlorophyll and proline contents of $C$. equisetifolia and $C$. obesa plants in salt stress condition. These positive effects were more important in $C$. obesa plants amended with Casuarina leaves compost. This study shows that Casuarina leaves compost can play an important role in the rehabilitation of saline soils by improving Casuarina trees performance in saline conditions.

\section{Keywords}

Frugal Innovation, Rehabilitation of Salty Lands, Casuarina, Compost, Crushed Nodules, Rhizospheric Soil

\section{Introduction}

Salinity is a major abiotic stress affecting crop yield in the Sahel [1]. Salinization can be defined as a process of accumulating soluble salts in the soil at high levels that can negatively affect agricultural production or cause biodiversity degradation [2]. Lands affected by salinity are estimated worldwide at about 932.2 million hectares [3]. In Africa, salinization affects 40 million hectares of land and 15 million hectares of these lands are directly linked to anthropogenic factors [4]. In Senegal, about $1,200,000$ hectares of land are reported to be affected by salinization, representing nearly $6 \%$ of the country's total area. According to Diack et al. [5], this area has increased to $1,700,000$ ha, which considerably affects agricultural production potential. In arid and semi-arid ecosystems, salinization results from high water evaporation and irregular and deficient rainfall [6]. This salinization leads to land degradation and adverse effects on soil fauna and plants, resulting in decreased soil fertility and lower agricultural yields [7]. Today, with the growing need for agricultural and forestry production, land rehabilitation has become a major challenge to meet this high demand. Several methods have been used to rehabilitate saline soils, which include mechanical methods, chemical methods and biological methods.

Thus, one of the sustainable and environmentally friendly strategies for improving agricultural production and rehabilitating degraded ecosystems would be the use of salt tolerant plants associated with symbiotic microorganisms that can enhance the salt tolerance of these plants.

Plants belonging to the Casuarinaceae family are pioneer species widely used in the rehabilitation of poor soils [8] thanks to their ability to form a relationship with symbiotic microorganisms such as nitrogen fixing bacteria and arbuscular mycorrhizal fungi. These symbiotic associations improve the $\mathrm{N}$ and Pi nutrition 
of the plant [9]. Several species belonging to this family such as $C$. obesa and $C$. equisetifolia are salt tolerant [10]. The inoculation of these plants with symbiotic microorganisms such as AMF and/or Frankia has been shown to improve salt tolerance [11] [12]. However, in Senegal inocula are made of nitrogen fixing bacteria or AMF are not accessible to producers. Thus, the aim of this study was to test alternative types of inocula such as crushed nodules containing nitrogen-fixing bacteria from adult Casuarina plants, $C$. equisetifolia canopy soil which may contain symbiotic microorganisms such as mycorrhizal fungi, nitrogen-fixing bacteria and Plant Growth Promoting Rhizobacteria (PGPR), and a compost derived from Casuarina leaves litter (Casuarina compost) which is commonly found in Senegal [13] and may also contain beneficial microrganisms and nutrients that improve salt tolerance of $C$. equisetifolia and $C$. obesa. These different types of amendments have several advantages: they are very accessible, easy to produce and cheap and are therefore likely to be adopted by producers. These inocula will be an alternative to biofertilizers such as Rhizobia and AMF which are not available to farmers in Senegal and would be difficult to produce and relatively expensive.

\section{Material and Methods}

\subsection{Plant Material}

Seeds of Casuarina equisetifolia (L. Johnson) harvested at Notto Gouye Diama $\left(14^{\circ} 59^{\prime} 29.89^{\prime \prime} \mathrm{N}, 17^{\circ} 00^{\prime} 35.97^{\prime \prime} \mathrm{O}\right)$, batch SN/2008/0018/D in the north of the Thiès region were provided by PRONASEF (National Forest Seed Program). Casuarina obesa (Miq.) seeds (lot 15777) were provided by CSIRO (Australian Tree Seed Center). They were harvested in the locality of Mullewa, Australia, at a latitude of $28^{\circ} 15^{\prime}$ North, a longitude of $115^{\circ} 38^{\prime}$ East and an altitude of $250 \mathrm{~m}$. About 2800 viable seeds were counted in a batch of $10 \mathrm{~g}$. These seeds were not pretreated and were stored at $4^{\circ} \mathrm{C}$ in the laboratory.

\subsection{Cultivation Substrates}

Experiments were performed using a sandy soil collected at ISRA/CNRA (Institute Senegalese of Agriculture Research/National Center for Agronomical Research, Bambey, Senegal) $\left(14^{\circ} 71\right.$ North $\left.-16^{\circ} 48 \mathrm{West}\right)$ at the horizon $(0-30 \mathrm{~cm})$. This soil was sieved through a $2 \mathrm{~mm}$ mesh and homogenized to eliminate plant debris. The physicochemical characteristics of the soil sample were determined at laboratory of soil, plant and water, ISRA/CNRA, Bambey, Senegal (Table 1).

Table 1. Physical and chemical characteristics of the soils.

\begin{tabular}{|c|c|c|c|c|c|c|c|c|c|}
\hline & \multicolumn{2}{|c|}{$\mathrm{pH}$} & \multirow{2}{*}{$\begin{array}{c}\mathrm{CE} \\
\mu \mathrm{S} / \mathrm{cm}\end{array}$} & \multirow{2}{*}{$\begin{array}{c}\text { Soluble } \\
\text { phosphorus } \\
\text { ppm }\end{array}$} & \multirow{2}{*}{$\begin{array}{c}\text { Total } \\
\text { phosphorus } \\
\text { ppm }\end{array}$} & \multirow{2}{*}{$\begin{array}{c}\text { Organic } \\
\text { carbon } \\
(\%)\end{array}$} & \multirow{2}{*}{$\begin{array}{c}\text { Total } \\
\text { nitrogen } \\
(\%)\end{array}$} & \multirow{2}{*}{$\begin{array}{c}\text { Organic } \\
\text { matter } \\
(\%)\end{array}$} & \multirow{2}{*}{$\mathrm{C} / \mathrm{N}$} \\
\hline & $\mathrm{H}_{2} \mathrm{O}$ & $\mathrm{KCl}$ & & & & & & & \\
\hline Soil from CNRA Bambey center (Senegal) & 7.78 & 7.46 & 218.4 & 8.915 & 3.896 & 0.631 & 0.057 & 1.087 & 11.15 \\
\hline Casuarina rhizopheric soil & 8.05 & 7.64 & 287.3 & 8.433 & 3.685 & 0.717 & 0.079 & 1.24 & 9,11 \\
\hline
\end{tabular}


The soil was autoclaved at $120^{\circ} \mathrm{C}$ for 2 hours and stored at $-30^{\circ} \mathrm{C}$ to eliminate microorganisms.

\subsection{The Different Types of Amendments}

The fresh nodules and the Casuarina rhizospheric soil (CRS) $(0-20 \mathrm{~cm}$ horizon) used in this experiment were collected from $C$. equisetifolia adult plants at $12^{\circ} 8^{\prime}$ and $16^{\circ} 41^{\prime}$ north latitude and $11^{\circ} 21^{\prime}$ and $17^{\circ} 32^{\prime}$ west longitude in the Niayes area where a Casuarina plantation was established in 1920. Casuarina leaves compost was delivered by the Horticultural Development Centre (ISRA/CDH); its physical and chemical characteristics were determined at the laboratory of soil, plant and water, ISRA/CNRA, Bambey, Senegal (Table 2). The fresh nodules were washed several times with tap water, then 3 times with sterile distilled water. $20 \mathrm{~g}$ of nodules were crushed in a mortar. The crushed nodules thus obtained were suspended in $500 \mathrm{ml}$ of sterile distilled water before inoculation. Soil collected under the $C$. equisetifolia trees was sieved to $2 \mathrm{~mm}$ and the fine soil was mixed with autoclaved Bambey sand respectively $1 / 4$ and 3/4.

\subsection{Experimentation Design}

C. obesa and $C$. equisetifolia seeds were germinated in $23.5 \mathrm{~cm} \times 9.5 \mathrm{~cm}$ polyethylene bags filled with sterile soil. Soils were previously sterilized by autoclaving at $120^{\circ} \mathrm{C}$ for $20 \mathrm{mn}$ to prevent colonization by native AMF/ectomycorrhizal fungi and/or Frankia, and thus to analyze the effects of the amendments. Two months old seedlings were transferred into pots $(25 \times 12 \times 50 \mathrm{~cm})$ filled with sterilized soil and kept in a greenhouse at $\approx 30^{\circ} \mathrm{C}$ at the ISRA/CNRA, Bambey.

Different treatments were carried out: plants inoculated with Casuarina leaves compost (hereafter called Casuarina compost), Casuarina rhizospheric soil (hereafter called Casuarina soil) or Casuarina crushed nodules (hereafter called crushed nodules). The quantity of $C$. equisetifolia leaves compost or Casuarina rhizospheric soil added in the polyethylene bags filled with sterile soil was $1 / 4$ of the substrate. For crushed nodules, a suspension of $5 \mathrm{ml}(0.4 \mathrm{~g}$ of nodules $/ \mathrm{mL})$ was added directly to the substrate during transfer near the root system to promote contact of symbiotic microorganisms and the plant. Control plants were transplanted directly to the sterile substrate.

The plants were watered with distilled water for 1 month, to allow the establishment of symbiosis and allow time for the plants to adapt to post-transplant stress. Then, plants were subjected to salt stress by applying different treatments of sodium chloride $(\mathrm{NaCl})(0 \mathrm{mM}, 150 \mathrm{mM}$ and $300 \mathrm{mM})$ until the end of the

Table 2. Chemical characteristics of $C$. equisetifolia compost.

\begin{tabular}{lccccccc}
\hline & $\begin{array}{c}\text { Total } \\
\text { phosphorus } \\
\text { ppm }\end{array}$ & $\begin{array}{c}\text { Organic } \\
\text { carbon } \\
(\%)\end{array}$ & $\begin{array}{c}\text { Total } \\
\text { nitrogen } \\
(\%)\end{array}$ & $\begin{array}{c}\text { Organic } \\
\text { matter } \\
(\%)\end{array}$ & $\mathrm{C} / \mathrm{N}$ & $\begin{array}{c}\mathrm{Na}^{+} \\
(\%)\end{array}$ & $\begin{array}{c}\mathrm{K}^{+} \\
(\%)\end{array}$ \\
\hline $\begin{array}{c}\text { C. } \text { equisetifolia } \\
\text { compost }\end{array}$ & 0.047 & 14.538 & 0.973 & 25.06 & 14.94 & 0.403 & 0.063 \\
\hline
\end{tabular}


experiment. Salt stress was gradually applied to avoid osmotic shock. For the first application, a concentration of $25 \mathrm{mM}$ corresponding to $1.46 \mathrm{~g} / \mathrm{L}$ was used. This concentration corresponds to a threshold beyond which most non-salt-resistant plant species cannot develop [14]. This concentration was increased gradually as described by Djighaly et al. [10] until reaching the desired concentration (150 $\mathrm{mM}$ or $300 \mathrm{mM}$ ). These concentrations constituted the daily watering solution for the plants and the salt concentration was regularly checked for saturation with an Extech portable salinity refractometer Z741839-1EA (Sigma).

The design included three factors: plant species (C. equisetifolia and C. obesa), amendment (crushed nodules, $C$. equisetifolia rhizospheric soil, C. equisetifolia leaves compost and controls), and salinity $(0,150,300 \mathrm{mM} \mathrm{NaCl})$. Twenty four (24) treatments $(2 \times 4 \times 3)$ were carried out with nine (9) replications per treatment.

After four months of growing in greenhouse, the plants were harvested and the following parameters were evaluated: survival rate, height growth, aerial and root biomass, chlorophyll and proline contents.

\subsection{Shoot Growth Total Dry Biomass Measurement and Survival Rate}

Shoot length was measured using a graduated ruler. After four months of growing, C. equisetifolia and C. obesa plants were harvested and the shoot and root systems were separated, washed in deionized water and dried at $70^{\circ} \mathrm{C}$ for $72 \mathrm{~h}$. The dried biomass of each sample was evaluated separately using an electronic precision scale. The survival rate was determined using the formula:

$$
\text { Survivalrate }(\%)=\frac{\text { number of survival plants }}{\text { number total of plants }} * 100
$$

\subsection{Chlorophyll and Proline Contents}

The chlorophyll content (a), (b), and $(\mathrm{a}+\mathrm{b})$ levels in $C$. equisetifolia and C. obesa plants were determined with $100 \mathrm{mg}$ of fresh leaves as described in Djighaly et al. [10].

Total chlorophyll contents (Chlorophyll a and b) were calculated from Arnon [15] according to the following formula:

$$
C H t\left(\mathrm{mg} \cdot \mathrm{g}^{-1}\right)=[8.02 \times O D 663 \mathrm{~nm}+20.2 \times O D 645 \mathrm{~nm}] \times V / M
$$

where $V$ is the volume of the total extract, $M$ the mass of the fresh material and $O D$ the optical density $(\mathrm{nm})$.

To determine the concentration of proline in the plants, $100 \mathrm{mg}$ of fresh shoots were ground and proline concentrations were quantified by spectrophotometry $(520 \mathrm{~nm})$ according to Monneveux and Nemmar [16].

\subsection{Statistical Analysis}

The data obtained was processed with the GENSTAT version 17 software (VSN International) and a Shapiro normality test was performed followed by a Levene 
test to check the equality of the variances. Finally, all data following the normality was analyzed using a two-way ANOVA test and a Newman and Keuls test to assess the effects of $\mathrm{NaCl}$ concentration and their interaction on survival rate, shoot height, total dry biomass, chlorophyll content and proline content with a significance threshold set at 0.05 .

\section{Results}

\subsection{Survival Rate of $C$. equisetifolia and $C$. obesa Plants under Salt Stress Conditions}

After four months of growing in greenhouse, the survival rate of $C$. equisetifolia and $C$. obesa plants was evaluated. In the absence of $\mathrm{NaCl}$, a survival rate of $100 \%$ was observed in C. equisetifolia and C. obesa (Table 3).

Table 3. Survival rates of $C$. equisetifolia and $C$. obesa after 4 months of cultivation.

\begin{tabular}{|c|c|c|c|}
\hline & Treatments & {$[\mathrm{NaCl}](\mathrm{mM})$} & Survival rates of plants (\%) \\
\hline \multirow[t]{12}{*}{ C. equisetifolia } & Control & 0 & $100 \mathrm{a}$ \\
\hline & & 150 & $100 \mathrm{a}$ \\
\hline & & 300 & $0-$ \\
\hline & Crushed nodules & 0 & $100 \mathrm{a}$ \\
\hline & & 150 & $88.9 \mathrm{a}$ \\
\hline & & 300 & $11.2 \mathrm{~d}$ \\
\hline & Casuarina compost & 0 & $100 \mathrm{a}$ \\
\hline & & 150 & $100 \mathrm{a}$ \\
\hline & & 300 & $22.3 \mathrm{~d}$ \\
\hline & Casuarina soil & 0 & $100 \mathrm{a}$ \\
\hline & & 150 & $88.9 \mathrm{a}$ \\
\hline & & 300 & $22.3 \mathrm{~d}$ \\
\hline \multirow[t]{12}{*}{ C. obesa } & Control & 0 & $100 \mathrm{a}$ \\
\hline & & 150 & $100 \mathrm{a}$ \\
\hline & & 300 & $44.5 \mathrm{c}$ \\
\hline & crushed nodules & 0 & $100 \mathrm{a}$ \\
\hline & & 150 & $100 \mathrm{a}$ \\
\hline & & 300 & $66.7 \mathrm{~b}$ \\
\hline & Casuarina compost & 0 & $100 \mathrm{a}$ \\
\hline & & 150 & $100 \mathrm{a}$ \\
\hline & & 300 & $100 \mathrm{a}$ \\
\hline & Casuarina soil & 0 & $100 \mathrm{a}$ \\
\hline & & 150 & $100 \mathrm{a}$ \\
\hline & & 300 & $55.6 \mathrm{~b}$ \\
\hline
\end{tabular}

Lowercase letters $(\mathrm{a}-\mathrm{c})$ indicate significant differences between the control and treated plants at $\mathrm{P}<0.05$. 
At $150 \mathrm{mM}$ of $\mathrm{NaCl}$, a survival rate of $100 \%$ was observed in C. equisetifolia plants inoculated with Casuarina compost, followed by the plants inoculated with crushed nodules (88.9\%) and plants inoculated with Casuarina soil (88.9\%).

A survival rate of $100 \%$ was also observed at $150 \mathrm{mM}$ of $\mathrm{NaCl}$ in control plants. At $300 \mathrm{mM}$, plants inoculated with Casuarina compost and Casuarina soil had the same survival rates of $22.3 \%$ in $C$. equisetifolia. A lower survival rate $11.2 \%$ was recorded in plants inoculated with crushed nodules. At $300 \mathrm{mM}$, no C. equisetifolia plants survived after four months of cultivation.

Higher survival rates were noted in C. obesa plants compared to C. equisetifolia in saline soil for all $\mathrm{NaCl}$ concentrations. At $300 \mathrm{mM}$, the highest survival rate was observed in C. obesa plants inoculated with Casuarina compost (100\%), followed by plants inoculated with crushed nodules (66.7\%) and Casuarina soil (55.6\%).

\subsection{Effect of Crushed Nodules, Casuarina Soil and Casuarina Compost on the Height of $C$. obesa and $C$. equisetifolia}

No significant difference was noted between controls and inoculated plants in $C$. equisetifolia at $0 \mathrm{mM}$ and $150 \mathrm{mM}$ (Table 4). At $300 \mathrm{mM}$, mortality of all control plants was observed while the inoculated plants survived. A significant decrease in height growth was noted at $300 \mathrm{mM}$ compared to control plants in $C$. equisetifolia. In $C$. obesa, inoculation with Casuarina compost improves the height at $300 \mathrm{mM}$ compared to controls plants. A comparison between the two species showed that height of $C$. obesa plants was significantly bigger than $C$. equisetifolia at all concentrations. In plants inoculated with Casuarina compost, $83 \%$ of difference was noted in height between $C$. obesa and C. equisetifolia at $300 \mathrm{mM} \mathrm{NaCl}$.

\subsection{Effect of Crushed Nodules, Casuarina Soil and Casuarina Compost on the Total Dry Biomass of $C$. obesa and $C$. equisetifolia}

The inoculation with Casuarina compost significantly increased the total dry

Table 4. Height of C. equisetifolia and C. obesa after 4 months of cultivation.

\begin{tabular}{cccccc}
\hline & \multicolumn{5}{c}{ Height $(\mathrm{cm})$} \\
\hline & $\begin{array}{c}\mathrm{NaCl} \\
\text { concentrations } \\
(\mathrm{mM})\end{array}$ & Control & $\begin{array}{c}\text { crushed } \\
\text { nodules }\end{array}$ & $\begin{array}{c}\text { Casuarina } \\
\text { compost }\end{array}$ & Casuarina soil \\
\hline Casuarina & 0 & $27.28 \pm 6.75 \mathrm{~b}$ & $24.63 \pm 4.30 \mathrm{~b}$ & $30.52 \pm 5.70 \mathrm{~b}$ & $29.51 \pm 4.48 \mathrm{~b}$ \\
equisetifolia & 150 & $22.73 \pm 2.86 \mathrm{~b}$ & $21.96 \pm 4.28 \mathrm{bc}$ & $24.88 \pm 5.47 \mathrm{~b}$ & $22.45 \pm 3.37 \mathrm{bc}$ \\
& 300 & - & $2.94 \pm 0.59 \mathrm{~d}$ & $5.94 \pm 1.06 \mathrm{~d}$ & $6.11 \pm 3.02 \mathrm{~d}$ \\
Casuarina obesa & 150 & $34.3 \pm 5.02 \mathrm{~b}$ & $34.55 \pm 6.08 \mathrm{~b}$ & $33.67 \pm 3.16 \mathrm{~b}$ & $35.33 \pm 5.66 \mathrm{~b}$ \\
& 300 & $15.37 \pm 6.14 \mathrm{c}$ & $23.6 \pm 6.79 \mathrm{bc}$ & $35.16 \pm 4.26 \mathrm{~b}$ & $19.64 \pm 6.34 \mathrm{bc}$ \\
\hline
\end{tabular}

Each value represents the height mean of plants $(n=9)$ used for each treatment. Lowercase letters $(a-d)$ indicate significant differences between the control and treated plants at $\mathrm{P}<0.05$. 
plant biomass by $51 \%$ and $58 \%$ respectively at 0 and $150 \mathrm{mM}$ of $\mathrm{NaCl}$ in $C$. equisetifolia (Table 5). At $300 \mathrm{mM}$, the control C. equisetifolia plants did not survive. The plants inoculated with Casuarina compost showed a significant increase in biomass of $51 \% 58 \%$ and $29.8 \%$ respectively at 0,150 and $300 \mathrm{Mm}$ $\mathrm{NaCl}$ for C. obesa. At $300 \mathrm{mM}$ of $\mathrm{NaCl}$, a difference of $94 \%$ and $92 \%$ was noted between $C$. obesa and $C$. equisetifolia biomasses respectively in plants inoculated with Casuarina compost and those inoculated with Casuarina soil.

\subsection{Effect of Crushed Nodules, Casuarina Soil and Casuarina Compost on the Total Chlorophyll Content of $C$. obesa and $C$. equisetifolia}

The results show higher total chlorophyll contents in C. equisetifolia plants inoculated with Casuarina compost compared to control plants at 0 and $150 \mathrm{mM}$ of $\mathrm{NaCl}$. The inoculation with Casuarina compost increased the chlorophyll content by $23 \%$ and $28 \%$ compared to the control C. equisetifolia plants respectively at 0 and $150 \mathrm{mM}$ in. However, at $300 \mathrm{mM}$, control plants did not survive in C. equisetifolia (Table 6).

The inoculation with Casuarina compost improved the total chlorophyll content of plants in the presence of salt in C. obesa at 150 and $300 \mathrm{mM}$. The inoculation with Casuarina compost increased the chlorophyll content by and $12.65 \%$ and $71 \%$ compared to the control plants in C. obesa at 150 and $300 \mathrm{mM}$ respectively (Table 6).

\subsection{Effect of Crushed Nodules, Casuarina Soil and Casuarina Compost on the Total Proline Content of $C$. obesa and $C$. equisetifolia}

In the absence of salt stress and in the presence of $150 \mathrm{mM}$ of $\mathrm{NaCl}$, inoculation with Casuarina compost significantly increased the proline content of the plants compared to control plants in C. equisetifolia (Table 7). An increase of $89 \%$ and $52 \%$ was noted in $C$. equisetifolia plants inoculated with Casuarina compost at 0 and $150 \mathrm{mM}$ respectively compared to control plants. In C. obesa, inoculation

Table 5. Total dry biomass of C. equisetifolia and C. obesa plants.

\begin{tabular}{cccccc}
\hline & \multirow{2}{*}{$\begin{array}{c}\mathrm{NaCl} \\
\text { Concentrations } \\
(\mathrm{mM})\end{array}$} & Control & $\begin{array}{l}\text { Total dry biomass }(\mathrm{cm}) \\
\text { nodules }\end{array}$ & $\begin{array}{c}\text { Casuarina } \\
\text { compost }\end{array}$ & $\begin{array}{c}\text { Casuarina } \\
\text { soil }\end{array}$ \\
\cline { 3 - 6 } & 0 & $2.26 \pm 1.04 \mathrm{~b}$ & $3.17 \pm 1.27 \mathrm{~b}$ & $4.70 \pm 1.72 \mathrm{a}$ & $3.25 \pm 0.83 \mathrm{~b}$ \\
Casuarina & 150 & $0.51 \pm 0.33 \mathrm{e}$ & $0.57 \pm 0.32 \mathrm{e}$ & $1.22 \pm 0.97 \mathrm{~d}$ & $0.81 \pm 0.51 \mathrm{e}$ \\
equisetifolia & 300 & - & $0.14 \pm 0.13 \mathrm{f}$ & $0.08 \pm 0.1 \mathrm{f}$ & $0.06 \pm 0.03 \mathrm{f}$ \\
& 0 & $3.42 \pm 1.28 \mathrm{~b}$ & $3.96 \pm 1.02 \mathrm{ab}$ & $3.08 \pm 0.79 \mathrm{~b}$ & $4.12 \pm 1.40 \mathrm{~b}$ \\
Casuarina obesa & 150 & $1.30 \pm 0.46 \mathrm{~cd}$ & $1.57 \pm 0.55 \mathrm{~cd}$ & $1.91 \pm 0.75 \mathrm{c}$ & $1.56 \pm 0.61 \mathrm{~cd}$ \\
& 300 & $0.45 \pm 0.32 \mathrm{e}$ & $0.80 \pm 0.59 \mathrm{e}$ & $1.51 \pm 0.51 \mathrm{~cd}$ & $0.76 \pm 0.42 \mathrm{e}$ \\
\hline
\end{tabular}

Each value represents the total dry biomass mean of plants $(n=9)$ used for each treatment. Lowercase letters $(\mathrm{a}-\mathrm{f})$ indicate significant differences between the control and treated plants at $\mathrm{P}<0.05$. 
Table 6. Chlorophyll content of $C$. equisetifolia and C. obesa after 4 months of greenhouse cultivation.

\begin{tabular}{cccccc}
\hline \multicolumn{5}{c}{ Chlorophyll content $\left(\mathrm{mg} \cdot \mathrm{g}^{-1}\right)$} \\
$\begin{array}{c}\text { NaCl } \\
\text { Concentrations } \\
(\mathrm{mM})\end{array}$ & Control & $\begin{array}{c}\text { crushed } \\
\text { nodules }\end{array}$ & $\begin{array}{c}\text { Casuarina } \\
\text { compost }\end{array}$ & $\begin{array}{c}\text { Casuarina } \\
\text { soil }\end{array}$ \\
\hline $\begin{array}{c}\text { Casuarina } \\
\text { equisetifolia }\end{array}$ & 0 & $1.15 \pm 0.13 \mathrm{e}$ & $1.20 \pm 0.22 \mathrm{e}$ & $1.50 \pm 0.17 \mathrm{~d}$ & $1.35 \pm 0.13 \mathrm{de}$ \\
& 150 & $1.01 \pm 0.26 \mathrm{e}$ & $1.13 \pm 0.19 \mathrm{e}$ & $1.41 \pm 0.20 \mathrm{de}$ & $1.26 \pm 0.21 \mathrm{e}$ \\
Casuarina obesa & 150 & - & $0.13 \pm 0.10 \mathrm{~g}$ & $0.30 \pm 0.22 \mathrm{~g}$ & $0.27 \pm 0.06 \mathrm{~g}$ \\
& 0 & $1.91 \pm 0.24 \mathrm{c}$ & $1.77 \pm 0.32 \mathrm{~cd}$ & $2.13 \pm 0.25 \mathrm{ab}$ & $1.78 \pm 0.29 \mathrm{~cd}$ \\
& 300 & $2.07 \pm 0.26 \mathrm{~b}$ & $2.27 \pm 0.48 \mathrm{ab}$ & $2.37 \pm 0.11 \mathrm{a}$ & $2.21 \pm 0.25 \mathrm{ab}$ \\
\hline
\end{tabular}

Each value represents the chlorophyll content of plants $(n=9)$ used for each treatment. Lowercase letters (a - g) indicate significant differences between the control and treated plants at $\mathrm{P}<0.05$.

Table 7. Proline content in C. equisetifolia and C. obesa after 4 months of cultivation.

\begin{tabular}{cccccc}
\hline & \multirow{2}{NaCl}{} & \multicolumn{4}{c}{ Proline content $\left(\mathrm{mg} \mathrm{g}^{-1}\right)$} \\
\cline { 3 - 6 } & $\begin{array}{c}\text { Concentrations } \\
(\mathrm{mM})\end{array}$ & Control & $\begin{array}{c}\text { crushed } \\
\text { nodules }\end{array}$ & $\begin{array}{c}\text { Casuarina } \\
\text { compost }\end{array}$ & Casuarina soil \\
\hline \multirow{2}{*}{$\begin{array}{c}\text { Casuarina } \\
\text { equisetifolia }\end{array}$} & 0 & $3.83 \pm 2.02 \mathrm{~g}$ & $5.24 \pm 3.76 \mathrm{~g}$ & $49.38 \pm 6.49 \mathrm{de}$ & $10.16 \pm 3.58 \mathrm{f}$ \\
& 150 & $49.57 \pm 3.26 \mathrm{de}$ & $57.06 \pm 12.31 \mathrm{~d}$ & $105.66 \pm 13.77 \mathrm{a}$ & $57.55 \pm 15.22 \mathrm{~d}$ \\
& 300 & - & $2.00 \pm 4.01 \mathrm{~g}$ & $15.39 \pm 3.12 \mathrm{f}$ & $13.83 \pm 3.90 \mathrm{f}$ \\
Casuarina & 0 & $63.27 \pm 15.59 \mathrm{~cd}$ & $50.81 \pm 6.78 \mathrm{c}$ & $93.63 \pm 20.62 \mathrm{~b}$ & $74.95 \pm 11.86 \mathrm{c}$ \\
obesa & 150 & $90.21 \pm 25.42 \mathrm{~b}$ & $93.59 \pm 12.22 \mathrm{~b}$ & $112.92 \pm 26.05 \mathrm{a}$ & $111.45 \pm 20.73 \mathrm{a}$ \\
& 300 & $16.78 \pm 22.48 \mathrm{f}$ & $60.58 \pm 23.58 \mathrm{~cd}$ & $97.78 \pm 20.73 \mathrm{~b}$ & $42.41 \pm 21.50 \mathrm{e}$ \\
\hline
\end{tabular}

Each value represents the proline content mean of plants $(n=9)$ used for each treatment. Lowercase letters $(\mathrm{a}-\mathrm{g})$ indicate significant differences between the control and treated plants at $\mathrm{P}<0.05$.

with Casuarina compost increased proline content by $32 \%, 20 \%$ and $82 \%$ respectively to 0,150 and $300 \mathrm{mM}$ of $\mathrm{NaCl}$ compared to the control plants (Table 7). A comparison between both species shows higher proline content in C. obesa compared to C. equisetifolia at 0,150 and $300 \mathrm{mM} \mathrm{NaCl}$.

\section{Discussion}

\subsection{Effect of Crushed Nodules, Casuarina Soil and Casuarina Compost on Survival Rate, Height and Total Dry Biomass of $C$. obesa and C. equisetifolia}

The survival rate after four months of greenhouse cultivation is higher in C. $o b$ esa compared to $C$. equisetifolia plants. This higher survival rate under salt stress conditions in $C$. obesa is probably due to a better salt tolerance of this species. Better tolerance of $C$. obesa compared to C. equisetifolia, C.cunninghiamiana and C. cristata has already been described by Van der Moezel et al. [17]. This difference was related to a better regulation of the $\mathrm{Na} / \mathrm{K}$ ratio. Among the dif- 
ferent types of amendments used in this experimentation, a better survival rate was noted in C. obesa plants inoculated with Casuarina compost at $300 \mathrm{mM}$. The result is possibly linked to the fact that Casuarina compost contains organic matter (OM) and also many nutrients such as N, C, Ca etc. for the plant [18]. The results of Lal [19] showed that the amount of OM is a determining factor in agricultural productivity. The characterization of the Casuarina leaves compost used revealed the presence of essential nutrients such as nitrogen, phosphorus, potassium and organic carbon. These essential nutrients in compost probably help to rebuild the physicochemical properties of the soil and restore microbial activity [20] [21]. In saline stress conditions, the OM contained in the compost promotes the flocculation of clays [22] [23], which increases air circulation in the soil and is essential for plant growth but also for the functioning of soil microorganisms.

Similar results were found by Sall et al. [24] and Soumaré et al. [25] who showed that organic matter had a significant impact on the structure and activity of the microbial community. The decomposition of $C$. equisetifolia litter under semi-arid conditions results in the release of many nutrients in the following order: $\mathrm{Ca}>\mathrm{N}>\mathrm{K}>\mathrm{Mg}>\mathrm{Na}>\mathrm{P}>\mathrm{Fe}>\mathrm{Zn}>\mathrm{Cu}>\mathrm{Cr}$ [26]. These high $\mathrm{Ca}^{2+}$ contents in C. equisetifolia litter could promote selective absorption of the $\mathrm{Ca}^{2+}$ ion during exchange and reduce $\mathrm{Na}^{+}$absorption [27] under saline stress conditions. This phenomenon, which is a saline stress resistance mechanism, limits the toxicity of $\mathrm{Na}+$ cations and could explain the higher survival rate, height and biomass in C. obesa and C. equisetifolia plants inoculated with Casuarina leaves compost under salt stress conditions. The better growth of plants inoculated with Casuarina leaves compost could also be explained by nitrogen nutrition due to the effect of assimilable nitrogen. Our analysis of the chemical characteristics of the compost showed a high level of nitrogen $(0.973 \%)$. Thus, the work of Diallo et al. [28] showed a higher nitrogen mineralization in soils previously amended with Casuarina litter. Compared to other species such as Faidherbia albida (Del.) Chev., Azadirachta indica A. Juss, Andropogon gayanus Kunth, Eragrostis tremula Hochst. ex Steud, these authors found higher nitrogen levels in soils amended with $C$. equisetifolia. Phosphorus that can be released by amending with $C$. equisetifolia plays a very important role in degraded soils. In combination with nitrogen, they improve plant performance. These results confirm those of Brito et al. [29] which showed that use of Acacia waste compost as an alternative component for horticultural substrates.

The mortality observed in control plants of $C$. equisetifolia at $300 \mathrm{mM}$ could be related to the threshold tolerance level of this species. Djighaly et al. [29] showed that increasing $\mathrm{NaCl}$ concentration decrease $C$. equisetifolia growth but inoculation with AMF but inoculation with AMF improves their performance in saline condition.

Results also showed that high $\mathrm{NaCl}$ concentrations reduced height growth of C. equisetifolia and C. obesa plants. Same results were obtained by Ly et al. [30], 
which provide information on the negative effect of salinity on the height growth of Jatropha curcas L. seedlings. However, it is important to remember that decreasing height growth would constitute an adaptation strategy to saline stress [31]. It allows the plant to reduce energy and resource costs and thus avoid stress. However, inoculation with Casuarina leaves compost improved the stress tolerance of plants of C. obesa and C. equisetifolia.

\subsection{Effect of Crushed Nodules, Casuarina Soil and Casuarina Compost on Chlorophyll and Total Proline Content of $C$. obesa and $C$. equisetifolia}

This study also revealed that the two species studied do not react in the same way for the synthesis of chlorophyll under saline stress conditions. In C. equisetifolia, the decrease in chlorophyll synthesis was observed under different salt concentrations. In contrast, in C. obesa, the highest chlorophyll levels were observed at 150 and $300 \mathrm{mM}$. This could be explained by the better salt tolerance that was reflected in the growth and survival rate under saline stress conditions for this species. However, the decrease in chlorophyll levels may be due to the inhibition of certain enzymes involved in the synthesis of photosynthetic pigments [32] due to the accumulation of $\mathrm{Na}+$ ions.

However, inoculation with Casuarina leaves compost improved the chlorophyll levels of both species even at high concentrations of $\mathrm{NaCl}$ (150 to 300 $\mathrm{mM})$. This positive effect of Casuarina leaves compost on chlorophyll synthesis in the presence of salt could be related to the fact that Casuarina leaves compost contains $\mathrm{Mg}^{2+}$ [26] which play an important function in photosynthesis [33] [34] [35].

As for proline, the levels vary with $\mathrm{NaCl}$ concentrations, the type of amendment and also according to the species. The amino acid proline is one of the most accumulated osmolytes in plants, in response to salinity and drought [36] [37]. Its accumulation allows plants to regulate intracellular osmotic pressure in order to avoid water losses that can cause cells desiccation [38] [39]. In the presence of salt, the highest proline levels were found in plants inoculated with Casuarina leaves compost in both C. equisetifolia and C. obesa. However, at high $\mathrm{NaCl}$ concentration $(300 \mathrm{mM})$, the highest proline contents were found in $C$. obesa plants inoculated with Casuarina leaves compost. This greater accumulation in proline confirms the salt tolerance of this species and its performance in saline soil. This proline maintains the homeostasis of the cells for the plants, allowing them to continue growing in a saline environment, compared to control plants.

\section{Conclusion}

Our results show a negative effect of salt stress on Casuarina plants. This negative effect is less pronounced in C. obesa compared to $C$. equisetifolia. The effect of salt stress on Casuarina plants growth and development is mitigated by adding compost or biofertilizers. Casuarina compost amendment is more effective 
on Casuarina performance in poor soil affected by salinity when compared with crushed nodules or Casuarina soil amendment. Thus the improvement in plant growth was linked to nutrient supply from the Casuarina compost. The Casuarina compost could be an alternative biofertilizer to improve productivity in poor and saline soil. However, I will be very interesting to compare the effect of the amendment and the effect of pure Frankia inoculum and further works may be done to study the integration of other sources of organic matter and to optimize plant resistance to salinity.

\section{Data Availability}

The datasets generated and/or analyzed during the current study are available from the corresponding author on reasonable request.

\section{Acknowledgements}

This work was supported by the International Foundation for Sciences (IFS, no. $\mathrm{AD} / 22680$ ), the Academy of Sciences for the Developing World (TWAS, no. 11-214 RG/BIO/AF/AC I), The "Fonds d'Impulsion de la Recherche Scientifique et Technique" (FIRST) of the Ministry of Higher Education and Research of Senegal. The "Laboratoire Mixte International Adaptation des Plantes et microorganismes associés aux Stress Environnementaux" (LAPSE).

\section{Conflicts of Interest}

The authors declare no conflicts of interest regarding the publication of this paper.

\section{References}

[1] Jabbar, M. and Chen, X.L. (2008) Land Degradation Due to Salinization in Arid and Semi-Arid Regions with the Aid of Geo-Information Techniques, Geo-Spatial Information. Science, 11, 112-120. https://doi.org/10.1007/s11806-008-0013-Z

[2] Rengasamy, P. (2006) World Salinization with Emphasis on Australia. Journal of Experimental Botany, 57, 1017-1023. https://doi.org/10.1093/jxb/erj108

[3] Shahid, S.A., Zaman, M. and Heng, L. (2018) Soil Salinity: Historical Perspectives and a World Overview of the Problem. In: Zaman, M., Shahid, S.A. and Heng, L., Eds., Guideline for Salinity Assessment, Mitigation and Adaptation Using Nuclear and Related Techniques, Springer International Publishing, Cham, 43-53. https://doi.org/10.1007/978-3-319-96190-3_2

[4] FAO (2008) Land and Plant Nutrition Management Service. http://www.fao.org/ag/agl/agll/spush

[5] Diack, M., Diop, T. and Ndiaye R. (2019) Restoration of Degraded Lands Affected by Salinization Process under Climate Change Conditions: Impacts on Food Security in the Senegal River Valley. Springer, Berlin, 275-288. https://doi.org/10.1007/978-3-319-09360-4_14

[6] Munns, R., James, R.A. and Läuchli, A. (2006) Approaches to Increasing the Salt Tolerance of Wheat and Other Cereals. Journal of Experimental Botany, 57, 1025-1043. https://doi.org/10.1093/jxb/erj100 
[7] Kopittke, P.M., Menzies, N.W., Wang, P., Mckenna, B.A. and Lombi, E. (2019) Soil and the Intensification of Agriculture for Global Food Security. Environment International, 132, Article ID: 105078. https://doi.org/10.1016/j.envint.2019.105078

[8] Sayed, W.F. (2011) Improving Casuarina Growth and Symbiosis with Frankia under Different Soil and Environmental Conditions-Review. Folia Microbiologica, 56, 1-9. https://doi.org/10.1007/s12223-011-0002-8

[9] Diagne, N., Diouf, D., Svistoonoff, S., Kane, A., Noba, K., Franche, C., Bogusz D. and Duponnois R. (2013) Casuarina in Africa: Distribution, Role and Importance of Arbuscular Mycorrhizal, Ectomycorrhizal Fungi and Frankia on Plant Development. Journal of Environment Management, 128, 204-209. https://doi.org/10.1016/j.jenvman.2013.05.009

[10] Djighaly, P.I., Diagne, N., Ngom, M., Ngom, D., Hocher, V., Fall, D., Diouf, D., Laplaze, L., Svistoonoff, S. and Champion, A. (2018) Selection of Arbuscular Mycorrhizal Fungal Strains to Improve Casuarina equisetifolia L. and Casuarina glauca Sieb. Tolerance to Salinity. Annals of Forest Science, 75, Article No. 72. https://doi.org/10.1007/s13595-018-0747-1

[11] Diagne, N., Djighaly, P., Ngom, M., Prodjinoto, H., Ngom, D., Hocher, V., Fall, D., Diouf, D., Nambiar-Veetil, M., Sy, M., Ndoye, I., Franche, C., Bogusz, D. and Laplaze, L. (2014) Rehabilitation of Saline Lands Using Selected Salt-Tolerant Casuarina-Microorganisms Combinations. 5th International Casuarina Meeting, 3-7 February 2003, Chennai. https://www.researchgate.net/publication/276290613

[12] Ngom, M., Gray, K., Diagne, N., Oshone, R., Fardoux, J., Gherbi, H., Hocher, V., Svistoonoff, S., Laplaze, L., Tisa, L.S., Sy, M.O. and Champion, A. (2016) Symbiotic Performance of Diverse Frankia Strains on Salt-Stressed Casuarina glauca and Casuarina equisetifolia Plants. Frontiers in Plant Science, 7, 1331.

[13] Diagne, N., Ngom, M., Djighaly, P.I., Cissokho, M. and Sy, M.O. (2015) Casuarina equisetifolia: A Multipurpose Nitrogen Fixing Tree in Senegal. NFT News, IUFRO, Vol. 12, No. 1, 3-4.

[14] Faye, S., Maloszewski, P., Stichler, W., Trimborn, P., Cissé, S.F. and Bécaye, C.G. (2005) Groundwater Salinization in the Saloum (Senegal) Delta Aquifer: Minor Elements and Isotopic Indicators. The Science of the Total Environment, 343, 243-259. https://doi.org/10.1016/j.scitotenv.2004.10.001

[15] Arnon, D.I. (1949) Copper Enzymes in Isolated Chloroplasts. Polyphenoloxidase in Beta vulgaris. Plant Physiology, 24, 1-15. https://doi.org/10.1104/pp.24.1.1

[16] Monneveux, P. and Nemmar, M. (1986) Contribution à l'étude de la résistance à la sécheresse chez le blé tendre (Triticum aestivum L.) et chez le blé dur (Triticum durum Desf.): Étude de l'accumulation de la proline au cours du cycle de développement. Agronomie, 6, 583-590. https://doi.org/10.1051/agro:19860611

[17] Van der Moezel, P.G., Walton, C.S., Pearce-Pinto, G.V.N. and Bell, D.T. (1989) Screening for Salinity and Waterlogging Tolerance in Five Casuarina Species. Landscape and Urban Planning, 17, 331-337. https://doi.org/10.1016/0169-2046(89)90087-X

[18] Saqib, H.M.U., Ahmad, I., Rashid, M.H.U., Farooq, T.H., Asif, M., Kashif, M., Iqbal, A. and Nawaz, M.F. (2019) Effect of Compost Application on the Growth of Acacia Nilotica, Cercetari Agronomice in Moldova, 52, 66-73. https://doi.org/10.2478/cerce-2019-0007

[19] Lal, R. (2004) Soil Carbon Sequestration Impacts on Global Climate Change and Food Security. Science, 304, 1623-1627. https://doi.org/10.1126/science.1097396

[20] Cogger, C.G. (2005) Potential Compost Benefits for Restoration of Soils Disturbed 
by Urban Development. Compost Science \& Utilization, 13, 243-251. https://doi.org/10.1080/1065657X.2005.10702248

[21] Bastida, F., Selevsek, N., Torres, I.F., Hernández, T. and García, C. (2015) Soil Restoration with Organic Amendments: Linking Cellular Functionality and Ecosystem Processes. Scientific Reports, 5, Article ID: 15550. https://doi.org/10.1038/srep15550

[22] Peinemann, N., Guggenberger, G. and Zech, W. (2005) Soil Organic Matter and Its Lignin Component in Surface Horizons of Salt-Affected Soils of the Argentinian pampa. CATENA, 60, 113-128. https://doi.org/10.1016/j.catena.2004.11.008

[23] Bischoff, N., Mikutta, R., Shibistova, O., Dohrmann, R., Herdtle, D., Gerhard, L., Fritzsche, F., Puzanov, A., Silanteva, M., Grebennikova, A. and Guggenberger, G. (2018) Organic Matter Dynamics along a Salinity Gradient in Siberian Steppe Soils, Biogeosciences, 15, 13-29. https://doi.org/10.5194/bg-15-13-2018

[24] Sall, S.N., Masse, D., Bernhard-Reversat, F., Guisse, A. and Chotte, J.-L. (2003) Microbial Activities during the Early Stage of Laboratory Decomposition of Tropical Leaf Litters: the Effect of Interactions between Litter Quality and Exogenous Inorganic Nitrogen. Biology and Fertility of Soils, 39, 103-111. https://doi.org/10.1007/s00374-003-0679-1

[25] Soumaré, M., Fm, T. and Mg, V. (2003) Characterisation of Malian and Belgian Solid Waste Composts with Respect to Fertility and Suitability for Land Application. Waste Management, 23, 517-522. https://doi.org/10.1016/S0956-053X(03)00067-9

[26] Uma, M., Saravanan, T. and Rajendran, K. (2014) Growth, Litterfall and Litter Decomposition of Casuarina equisetifolia in a Semi-Arid Zone. Journal of Tropical Forest Science, 26, 125-133.

[27] Nelson, P.N. and Oades, J.M. (1998) Organic Matter, Sodicity and Soil Structure, In: Sumner, M.E. and Naidu, R., Eds., Sodic Soils. Distribution, Properties, Management and Environmental Consequences, Oxford University Press, New York, 51-75. https://researchonline.jcu.edu.au/224/

[28] Diallo, M.-D., Guisse, A., Badiane-Niane, A., Sall, S. and Chotte, J.-L. (2005) In Situ Effect of Some Tropical Litters on N Mineralization. Arid Land Research and Management, 19, 173-181. https://doi.org/10.1080/15324980590916576

[29] Brito, L.M., Reis, M., Mourão, I. and Coutinho, J. (2015) Use of Acacia Waste Compost as an Alternative Component for Horticultural Substrates. Communications in Soil Science and Plant Analysis, 46, 1814-1826. https://doi.org/10.1080/00103624.2015.1059843

[30] Ly, M., Kumar, D., Diouf, M., Nautiyal, S. and Diop, T. (2014) Effet de la salinité sur la croissance et la production de biomasse de deux provenances de Jatropha curcas L. cultivés en serre. International Journal of Biological and Chemical Sciences, 8, 46-56. https://doi.org/10.4314/ijbcs.v8i1.5

[31] Diallo, M., Diaité, B., Diedhiou, I. and Diedhiou, P. (2017) Étude de la sensibilité de trois accessions de Jatropha Curcas L. en condition de stress salin. Revue Sciences de La Vie, de La Terre et Agronomie Du Cames. 4.

[32] Sayyad-Amin, P., Jahansooz, M.-R., Borzouei, A. and Ajili, F. (2016) Changes in Photosynthetic Pigments and Chlorophyll- $\alpha$ Fluorescence Attributes of Sweet-Forage and Grain Sorghum Cultivars under Salt Stress. Journal of Biological Physics, 42, 601-620. https://doi.org/10.1007/s10867-016-9428-1

[33] Giri, B. and Mukerji, K.G. (2004) Mycorrhizal Inoculant Alleviates Salt Stress in Sesbania aegyptiaca and Sesbania grandiflora under Field Conditions: Evidence for Reduced Sodium and Improved Magnesium Uptake. Mycorrhiza, 14, 307-312. 
https://doi.org/10.1007/s00572-003-0274-1

[34] Parida, A.K. and Das, A.B. (2005) Salt Tolerance and Salinity Effects on Plants: A Review. Ecotoxicology and Environmental Safety, 60, 324-329.

https://doi.org/10.1016/j.ecoenv.2004.06.010

[35] Navarro, J.M., Torres, R., Acuña, K., Duarte, C., Manriquez, P.H., Lardies, M., Lagos, N.A., Vargas, C. and Aguilera, V. (2013) Impact of Medium-Term Exposure to Elevated $p \mathrm{CO}_{2}$ Levels on the Physiological Energetics of the Mussel Mytilus chilensis. Chemosphere, 90, 1242-1248.

https://doi.org/10.1016/j.chemosphere.2012.09.063

[36] Watanabe, S., Kojima, K., Ide, Y. and Satohiko, S. (2000) Effects of Saline and Osmotic Stress on Proline and Sugar Accumulation in Populus euphratica in Vitro. Plant Cell, Tissue Organ Culture 63, Article No. 199.

https://doi.org/10.1023/A:1010619503680

[37] Sharma, A., Shahzad, B., Kumar, V., Kohli, S.K., Sidhu, G.P.S., Bali, A.S., Handa, N., Kapoor, D., Bhardwaj, R. and Zheng, B. (2019) Phytohormones Regulate Accumulation of Osmolytes under Abiotic Stress. Biomolecules, 9, 285.

https://doi.org/10.3390/biom9070285

[38] Hoque, M.A., Banu, M.N.A., Nakamura, Y., Shimoishi, Y. and Murata, Y. (2008) Proline and Glycinebetaine Enhance Antioxidant Defense and Methylglyoxal Detoxification Systems and Reduce NaCl-Induced Damage in Cultured Tobacco Cells. Journal of Plant Physiology, 165, 813-824. https://doi.org/10.1016/j.jplph.2007.07.013

[39] Iqbal, M.J. (2018) Role of Osmolytes and Antioxidant Enzymes for Drought Tolerance in Wheat. IntechOpen. https://doi.org/10.5772/intechopen.75926 